\title{
NAFKAH WANITA KARIER DALAM PERSPEKTIF FIKIH KLASIK
}

\author{
B. Syafuri \\ Fakultas Syariah IAIN Sultan Maulana Hasanuddin Banten \\ Jl. Jenderal Sudirman No. 30, Serang, Banten, 42118 \\ E-mail: hbsyafuri@gmail.com
}

\begin{abstract}
Support Payments of Career Woman within the Perspective of Classical Fiqh. This article attempts to research the right to support payments of career woman or woman in work. In traditional classic fiqh, the husband is liable to provide for support payments to his wife based on the principle of separation of property between husband and wife. This principle follows a flow of thought that a husband earns money instead of the wife. The understanding of the working wife or career woman which must be made dependent to the husband's permission needs to be re-examined or reviewed because the scholars have not mentioned the obvious arguments concerning the matter. Likewise, no proposition exists which prohibits, either men or women, to work as well as no firm proposition about the need to have the husband's permission to go to work. Similarly, many historical facts reveal that there were working women or career women in the time of the Prophet, such as 'A'ishah, Ummu Mubâshir, and others.
\end{abstract}

Keywords: support payments (living support), career woman, nushûz

Abstrak: Nafkah Wanita Karier dalam Pespektif Fikib Klasik. Artikel ini mencoba meneliti tentang hak nafkah wanita karier atau perempuan yang bekerja. Dalam tradisi fikih klasik, suami berkewajiban memberikan nafkah kepada istrinya didasarkan pada prinsip pemisahan harta antara suami dan istri. Prinsip ini mengikuti alur pikir bahwa suami adalah pencari rezeki, sedangkan istri bukan pencari rezeki. Pemahaman istri bekerja atau wanita karier yang harus digantungkan kepada izin suami itu perlu dibaca ulang atau ditinjau kembali karena ulama tidak menyebutkan dalil yang jelas tentang hal itu. Dan juga tidak adanya dalil yang melarang, baik laki-laki maupun perempuan, untuk bekerja serta tidak ada dalil yang tegas tentang keharusan bekerja dengan izin suami. Begitu juga banyaknya fakta sejarah yang mengungkapkan wanita-wanita yang bekerja atau wanita karier di masa Nabi, seperti ‘Â’ishah, Ummu Mubâshir, dan lain-lain.

Kata Kunci: nafkah, wanita karier, nusyu (nushîz)

\section{Pendahuluan}

Nafkah atau nafaqah adalah suatu pemberian yang bersifat materi kepada seorang istri atau kerabatnya. Nafkah bukanlah mahar, karena nafkah diberikan seterusnya selama keduanya masih ada ikatan perjanjian atau ikatan darah. Nafaqah secara harfiah berarti pengeluaran atau sesuatu yang dikeluarkan oleh seseorang untuk orang-orang yang menjadi tanggung jawabnya, yaitu: istri, anak, orang tua, bahkan kerabat dekat. Pengeluaran ini harus diberikan untuk keperluankeperluan yang baik, ${ }^{1}$ tidak semena-mena, dan juga harus disesuaikan dengan adat atau tradisi setempat yang berlaku. Bahkan, khusus untuk nafkah orang tua, para fukaha menentukan beberapa syarat, di antaranya

Naskah diterima: 7 November 2012, direvisi: 10 Mei 2013, disetujui untuk terbit: 17 Mei 2013.

${ }^{1}$ Husen Muhammad, Fiqh Perempuan, (Yogyakarta: LKIS, 2001), h. 150 . tidak mampu. Apabila orang tua atau kerabat dekat tidak mampu dan miskin, maka seseorang berkewajiban memberikan nafkah kepada orang tua. Sedangkan dalam hal nafkah kepada kerabat dekat terjadi perbedaan pendapat di kalangan ulama. ${ }^{2}$

Nafkah istri adalah kewajiban seorang suami. Hal ini disepakati oleh jumhur ulama karena istri bertugas di dalam rumah untuk melayani suami dan anak-anak. Begitu pula istri harus izin kepada suaminya apabila

${ }^{2}$ Lihat Al-Sarkhasî, al-Mabsût, cet. I, (Bayrût: Matba’ah Saâdah,

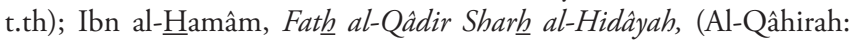
Matba'ah Mustafâ Muhammaad, t.th); Imâm Mâlik, al-Mudawwanah al Kubrâ Riwayat Sahnun, (Matba'ah al Saâdah, 1323 H); Ibn Rushd, Bidâyah al-Mujtahid, (Mišr: Mațba'ah al-Istiqâmah, t.th); Al-Sharbinî,

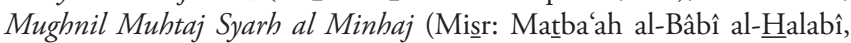
t.th); al-Ramlî, Nihâyah al-Muntaj, (Mišr: Matba'ah al-Bahiyah, t.th); Ibn Qudâmah, al-Mughnî, cet. III, (al-Qâhirah: Dâr al-Manâr, t.th); Abû al-Barakah, al-Muharrar fi al-Figh 'alâ Madhhab al-Imâm A $\underline{\text { hmad }}$ ibn $\underline{H}$ anbal, (Misir: Matba'ah al-Sunniyyah, t.th). 
hendak keluar rumah. Oleh karena itu, ketika istri bertugas atau berjasa pada ranah privat, maka seorang suami harus membayar jasanya berupa memberikan nafkah.

Namun muncul masalah dalam hal istri adalah wanita karier atau wanita yang bekerja dan meninggalkan keluarganya. Pertanyaannya, apakah seorang wanita tidak boleh bekerja atau mencari nafkah? Apakah hanya laki-laki yang boleh berkarier dan berusaha? Beberapa hal inilah yang ingin penulis uraikan dalam artikel bersahaja ini.

Penulis mencoba mengkritisi tentang nafkah istri dan masalah yang berkaitan dengannya. Selama ini, dalam tradisi fikih klasik, seorang suami berkewajiban memberikan nafkah kepada istrinya didasarkan kepada prinsip pemisahan harta antara suami dan istri. Prinsip ini mengikuti alur pikir bahwa suami adalah pencari rezeki. Harta yang telah diperolehnya tersebut kemudian menjadi haknya secara penuh. Selanjutnya, suami berkedudukan sebagai pemberi nafkah. Sebaliknya, istri bukan pencari rezeki dan untuk memenuhi keperluannya ia berkedudukan sebagai penerima nafkah. ${ }^{3}$

\section{Nafkah Istri}

Nafkah istri merupakan hak dasar istri dari suaminya. Seorang suami wajib memberikan nafkah kepada istrinya disebabkan adanya ikatan perkawinan. Ulama sepakat ${ }^{4}$ bahwa seorang suami wajib memberikaan nafkah kepada istrinya, baik dia Muslimah maupun kâfirah karena terikat perkawinan. Apabila terlihat adanya kerusakan dalam akad nikah atau batalnya pernikahan, maka seorang suami boleh meminta kembali nafkah yang telah diberikan kepadanya.

Untuk mengetahui dasar hukum atau dalil kewajiban nafkah, berikut ini penulis jabarkan dengan dalil naqlî maupun aqlî. Pertama, Alquran menyatakan tentang kewajiban suami memberikan nafkah kepada istri, antara lain:

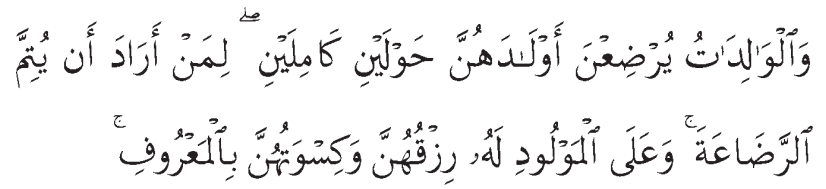

Para ibu hendaklah menyusukan anak-anaknya selama dua tahun penuh, yaitu bagi yang ingin menyempurnakan penyusuan. Dan kewajiban ayah memberi makan dan pakaian kepada para ibu dengan cara makruf. (Q.s. AlBaqarah [2]: 233)

${ }^{3}$ Amir Syarifudin, Hukum Perkawinan Islam di Indonesia, (Jakarta: Prenada Media Group, 2009), h. 165.

${ }^{4}$ Wahbah al-Zuhaylî, al-Fiqh al-Islâmî wa Adillatuh, juz VII, (Bayrût: Dâr al-Fikr: 2006), h. 786.

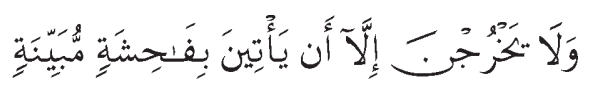

Dan janganlah mereka dikeluarkan kecuali mereka mengerjakan perbuatan keji yang terang. (Q.s. al-Talâq [65]: 1)

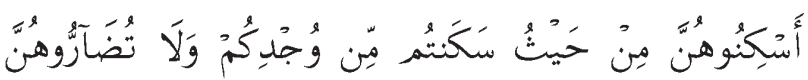

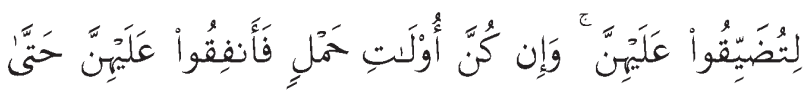

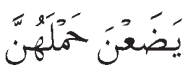

Tempatkanlah mereka (para istri) di mana kamu bertempat tinggal menurut kemampuanmu dan janganlah kamu menyusahkan mereka untuk menyempitkan (hati) mereka. Dan jika mereka (istri-istri yang sudah ditalak) itu sedang hamil, maka berikanlah kepada mereka nafkahnya hingga mereka bersalin. (Q.s. al-Talâq [65]: 6)

Ayat-ayat di atas mewajibkan nafkah secara sempurna bagi perempuan beridah, lebih wajib lagi bagi istri yang tidak ditalak.

Kedua, Hadis Rasulullah. Ketika berada di Arafah Rasulullah Saw. menyampaikan khotbah wada'-nya. Di antara isi khatbahnya adalah sebagai berikut:

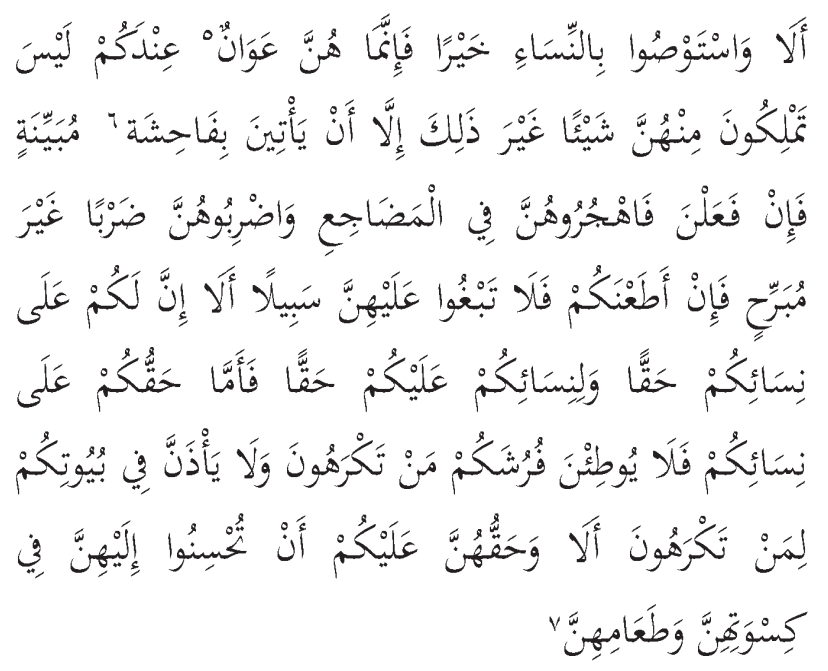

${ }^{5}$ Nawawi menafsirkan makna 'awân dengan tertahan. Artinya, istri tertahan oleh suami. Lihat Nawawi al-Bantani, Shar $\underline{h}$ Uqûd al-Lujayn, (Indonesia: Dâr Ihyâ al-Kutub al-'Arabiyyah, t.th.), h. 4. Sedangkan menurut Forum Kajian Kitab Kuning (FK3), Pimpinan Sinta Nuriyah Wahid, (Istri mantan Presiden R.I. Abdurrahman Wahid atau Gus Dur), kata 'awân bukan berarti menahan sebagaimana yang dikatakan Nawawi di atas. Akan tetapi kata 'awân berarti bahwa perempuan adalah di bawah naungan suami, maka dari Hadis di atas menunjukkan agar para suami melindungi para perempuan dan berbuat baik kepada para perempuan. Lihat Forum Kajian Kitab Kuning (FK3), Ta'liq

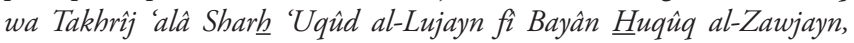
(Jakarta: FK3, t.th.), h.22.

${ }^{6}$ Kata fâhishah bagi Nawawi berarti nushûz. Lihat, Nawawi al-

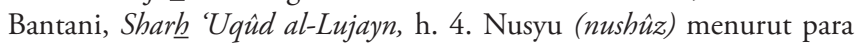
ulama mazhab adalah kedurhakaan istri terhadap suami dalam hal menjalankan apa-apa yang diwajibkan Allah atasnya. Atau sebagaimana dipahami dari surah al-Nisầ ayat 34, nusyu adalah tindakan melanggar perintah Allah Swt., seperti salat, istri, dan suami tidak menjaga kehormatan diri.

${ }^{7}$ Hadis ini terdapat dalam Sunan al-Turmudhî dan Sunan Ibn 
Ketahuilah olehmu bahwa kamu sekalian hendaknya melaksanakan wasiatku, yaitu melakukan hal yang terbaik bagi perempuan. Mereka itu tertahan di sisimu. Bagimu tidak ada pilihan lain dalam menghadapi mereka selain apa yang aku wasiatkan itu, kecuali kalau mereka melakukan fahisah secara jelas. Apabila mereka melakukannya, maka kamu sekalian hendaknya menghindar dari mereka di tempat peraduan dan berikanlah pukulan yang tidak memberatkan. Akan tetapi kalau mereka taat kepadamu, maka kamu sekalian tidak boleh mencari jalan untuk memukul mereka. Ketahuilah bahwa kamu sekalian mempunyai hak atas isterimu dan mereka pun mempunyai hak atas dirimu. Adapun hak kalian atas mereka adalah bahwa mereka itu tidak memperkenankan tilam milikmu tersentuh oleh orang lain yang tidak kamu sukai, dan tidak mengizinkan rumahmu dimasuki orang lain yang tidak kamu sukai pula. Dan ingatlah bahwa kamu sekalian harus menunjukkan kebaikanmu terhadap mereka baik dalam memberikan sandang maupun pangan. (H.r. alTurmudhî dan Ibn Mâjah).

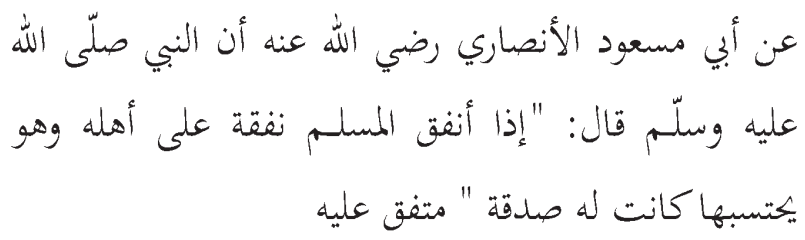

Dari Abû Mas'ûd al-Ansârî, bahwa Nabi Saw. bersabda, "Apabila seorang Muslim memberikan nafkah kepada keluarganya dan dia berharap mendapat ganjaran darinya, maka baginya seperti ganjaran sedekah.” (Muttafaq 'alayh)

$$
\begin{aligned}
& \text { عن أبي هريرة رضي الله عنه قال: قال رسول الله صلّى الله } \\
& \text { عليه وسلّم: " الساعي على الأرملة والمسكين كالبحاهد في } \\
& \text { سبيل الله, أو القائم الليل الصائم النهار " متفق عليه }
\end{aligned}
$$

Berkata Abû Hurayrah R.a. berkata, Rasulullah SAW bersabda: "Orang yang menanggung janda dan orang miskin seperti seorang yang berjihad di jalan Allah, atau seperti orang yang shalat malam dan berpuasa pada siang harinya” (Muttafaq 'alayh)

Mâjah. Teks Hadis dalam Sunan al-Turmudhî, Juz IV, h. 391, Hadis no. 1083 , lengkapnya adalah sebagai berikut:

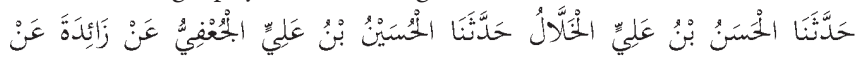

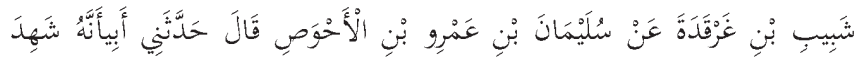

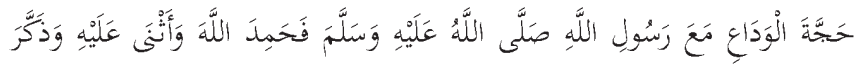

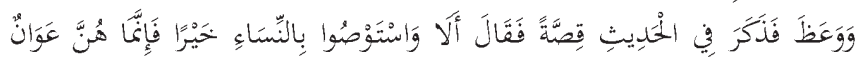

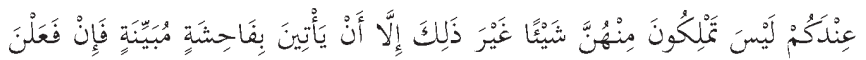

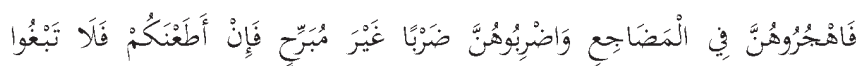

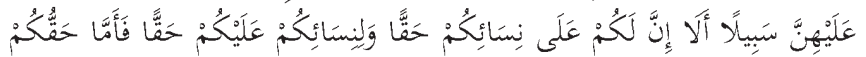

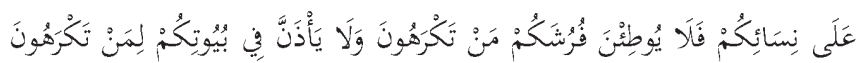

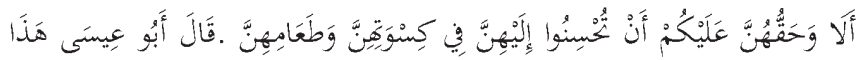

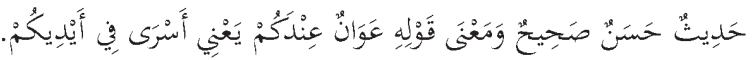

Hadis yang diriwayatkan al-Bukhârî dan Muslim dari Aishah R.a.:

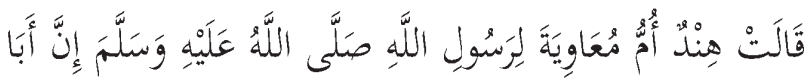

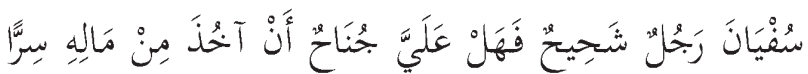

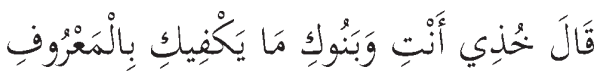

Bahwa Hindun bint 'Utbah bertanya, "Wahai Rasulullah, sesungguhnya Abû Sufyân seorang laki-laki yang pelit, ia tidak memberi aku sesuatu yang mencukupi aku dan anakku kecuali sesuatu yang aku ambil dari padanya dan ia tidak mengetahui". Rasulullah Saw. bersabda, "Ambillah sesuatu yang mencukupi engkau dan anak engkau dengan baik." (H.R. al-Bukhârî dan Muslim)

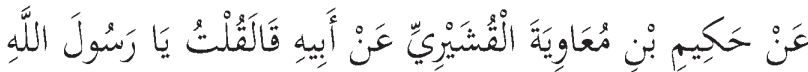

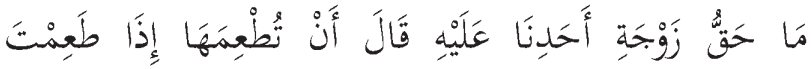

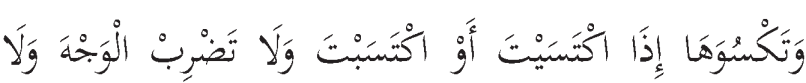

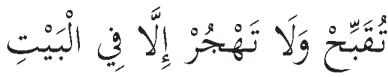

Dari Hakîm ibn Muâwiyah al-Qushyrî dari ayahnya, berkata, "Wahai Rasulullah, apa hak istri salah seorang di antara kami?" Rasulullah menjawab, "Engkau memberi makan kepadanya ketika engkau makan, memberi pakaian ketika engkau berpakaian, jangan engkau pukul muka, jangan engkau jelekkan, dan jangan engkau tinggal kecuali di dalam rumah”. (H.r. Ahmad, Abû Dâwud, al-Nasa'i, Ibn Mâjah, dan disahihkan oleh Ibn Hibbân dan Hakîm)

Ketiga, ijmak. Dalil ijmak, Ibn Qudâmah berkata, ${ }^{8}$ "Ahli ilmu sepakat wajibnya nafkah istri atas suami jika mereka telah berusia balig, kecuali istri yang nusyu (meninggalkan kewajiban sebagai istri). "Ibn Mundhir dan yang lain menyebutkannya dan berkata, "Di dalamnya ada pelajaran, bahwa perempuan yang tertahan dan tercegah berakivitas untuk bekerja, oleh suami wajib memberikan nafkah padanya."

Keempat, dalil 'aqlî. Bahwa seorang istri seperti terpenjara oleh suaminya karena harus melayani suaminya serta tidak adanya kesempatan bagi istri untuk keluar rumah dan bekerja maka secara akal untuk biaya keseluruhan seorang istri adalah seorang suami, karena ia telah mengabdikan segalanya kepada istrinya. Karena nafkah adalah sebagai imbalan bagi seorang istri yang telah melayani suaminya. ${ }^{9}$

\section{Nafkah Istri Berkarier}

Banyak perempuan yang bekerja pada zaman sekarang yang menuntut keluar dari rumah dan mengosong-

\footnotetext{
${ }^{8}$ Al-Mughnî, VIII, h. 195. Jika suami belum balig, nafkah diwajibkan atas wali.

${ }^{9}$ Wahbah al-Zuhaylî, al-Fiqh al-Islâmî wa Adillatuh, juz VII, h. 786.
} 
kannya di sebagian waktu. Lantas bagaimana nafkahnya?

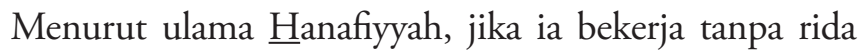
suami maka tidak wajib diberi nafkah, tetapi jika ia bekerja dengan ridanya, nafkah tetap wajib. Rida suami pada suatu waktu tidak otomatis menjadi keridaan di setiap waktu dan tempat, baginya boleh mencegah istri. Jika tidak mau, ia tergolong nusyu dan gugur nafkahnya. ${ }^{10}$

Hanya saja istri yang berkarier harus ikut memikul dari nafkah jika suami menuntut, karena pekerjaan perempuan didasarkan perhitungan kemaslahatan suami. Tentunya, tidak diragukan lagi bahwa kesibukan bekerja dan segala permasalahannya menyita banyak energi istri. Ia pulang ke rumah dalam keadaan lelah dan terpecah pikirannya. Ia butuh orang yang menghilangkan kepayahannya dan menenangkan jiwanya.

Jika pasangan suami-istri rida bahwa harta mereka menyatu maka tidak ada masalah, dan jika suami membiarkan gajinya dan tetap menanggung nafkahnya maka bagi suaminya pahala. Jika mereka berbeda pendapat, istri harus menanggung sebagian nafkah sebagian kompensasi kesepian, dan suami membiarkan status demikian karena 'urf dan kondisi lingkungan.

Sebagaimana telah penulis jelaskan, kebanyakan ulama fikih berpendapat bahwa tugas wanita adalah melayani suami dan urusan rumah tangga sehingga dengan demikian wanita yang baik adalah wanita yang berada di dalam rumah serta mengurusi suami dan anak-anaknya. Pendapat itu didasari oleh pemahaman mereka terhadap ayat-ayat Alquran dan Hadis. Akan tetapi, jika ditelisik kembali pemahaman itu tampaknya terjadi perbedaan pendapat di kalangan ulama. Di antara ayat Alquran yang menjadi dasar adalah surah al-Ahzâb [33] ayat 33 sebagai berikut:

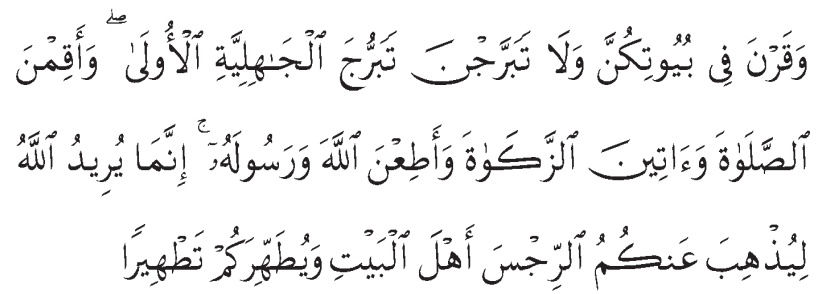

Dan hendaklah kamu tetap di rumahmu dan janganlah kamu berhias dan bertingkah laku seperti orang-orang Jahiliyah yang dahulu, dan dirikanlah salat, tunaikanlah zakat, dan taatilah Allah dan Rasul-Nya. Sesungguhnya Allah bermaksud hendak menghilangkan dosa dari kamu, wahai ahl al-bayt, dan membersihkan kamu sebersihbersihnya. (Q.s. al-Ahzâb [33]: 33)

\footnotetext{
${ }^{10}$ Abdul Aziz Muhammad Azzam dan Abdul Wahhab Sayyed Hawwas, Figh Munakahat, cet. I, terj. Abdul Majid Khon, (Jakarta: Amzah, 2009), h. 216.
}

Menurut Nasaruddin $\mathrm{Umar}^{11}$, dalam menafsirkan ayat di atas para Mufasir berbeda pendapat terutama mengenai kata وقرن yang menjadi kata kunci ayat ini. Ulama Madinah dan sebagian ulama Kufah membacanya sebagai "waqarna" yang berarti "tinggallah di rumah kalian dan tetaplah berada di sana". Sementara ulama-ulama Basrah dan sebagian ulama Kufah membaca "waqirna" yang berarti tinggallah di rumah kalian dengan tenang dan hormat. Kata وقرن dapat dibaca "waqarna" atau "waqirna". 12

Pendapat yang kedua ini didukung oleh Ibn Kathîr dan Jalal al-Dîn al-Suyûtî. ${ }^{13}$ Jika dibaca dengan model pertama, dengan baris fathah pada huruf qâf, maka dengan tegas perempuan diserukan untuk menetap di rumah. Kalau dibaca dengan model kedua, baris kasrah pada huruf qâf maka perempuan diserukan untuk bersenang-senang tinggal di rumah. Menurut Nasaruddin, pengertian pertama terkesan lebih tegas dari pada pengertian kedua. Kebanyakan kitab tafsir memperkenalkan bacaan versi pertama dengan penekanan kepada perempuan untuk menetap di dalam rumah. Contoh kitab tafsir tersebut antara lain, Tafsìr al-Munîr, ${ }^{14}$ Tafsîr al-Marâghî, ${ }^{15}$ Tafsìr Ibn Kathîr, ${ }^{16}$ dan tidak terkecuali kitab tafsir kontemporer seperti al-Asas fi al-Tafsîr li Fayd al-Hawa. ${ }^{17}$

Menurut al-Qurtubî, ayat tersebut bermakna perempuan Islam secara umum diperintahkan untuk menetap di dalam rumah, walaupun ia mengakui bahwa

${ }^{11}$ Nasarudin Umar, Fikih Wanita untuk Semua, (Jakarta: Serambi Ilmu, 2010), h. 144.

${ }^{12}$ Menurut al-Jâbarî, di dalam Tafsîr al-Jalâlayn, dikemukakan dua jenis qirẩah. Pertama, "waqarna" dengan baris fathah pada huruf qâf,

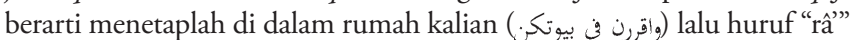
pertama dibuang sebagaimana yang terjadi pada (فظللتم تفكهون) dalam surah al-Wâqi'ah ayat 65, yang juga huruf "lâm" pertama dibuang. Teks lengkapanya adalah sebagai berikut:

( وَقَرَنَ ) بكسر القاف وفتـحها ( وِن بُيُوتِكُنَّ ) من القرار، وأصله: اقررن،

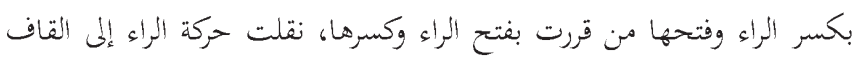

$$
\text { وحففت مع هزة الوصل }
$$

Lihat, Jalâl al-Dîn al-Suyûtîi, juz II, h. 108.

${ }^{13}$ Lihat, Tafsîr al-Tabarî, jilid XXII, h. 2-3; Lihat juga, Jalâl alDîn al-Suyûtîi dan Jalâl al-Dîn al-Mahallî, Tafsî̀ al-Jalalayn, juz II, h. 108; Bandingkan dengan pendapat al-Mawdûdî sebagaimana yang diungkapkan M. Quraish Shihab dalam "Konsep Perempuan Menurut al-Qur'an, Hadis, dan Sumber-sumber Ajaran Islam" dalam, Lies M. Marcoes dan Johan Hendrik Meuleman, Perempuan Islam Indonesia dalam Kajian Tekstual dan Konstekstual, (Jakarta: INIS, 1993), h. 8.

${ }^{14}$ Nawawi al-Jâwî al-Bantanî, Marah al-Labid Tafsîr al-Munîr, juz II, (Bayrût: Dâr al-Fikr, 1981), h. 183.

${ }^{15}$ Ahmad Mustafâ al-Marâghî, Tafsî̀ al-Marâghî, juz VIII, h. 7.

${ }^{16}$ Ibn Kathîr, Tafsîr Ibn Kathîr, juz III, (Bayrût: Dâr al-Fikr, 1986).

${ }^{17}$ Faid al-Hawâ, al-Asas fi al-Tafsîr, juz VIII, (Mišr: Dâr al-Salâm, 1999), h. 4435. 
sebenarnya redaksi ayat ini ditujukan kepada istri-istri nabi Muhammad Saw., tetapi para perempuan selain mereka juga dicakup dalam perintah tersebut. ${ }^{18}$ Bisa jadi, ini disebabkan karena istri- istri Nabi adalah Umm al-Müminin (ibu orang-orang Mukmin) yang menjadi teladan bagi seluruh perempuan Muslim. Oleh karena itu, perintah kepada istri Nabi Muhammad Saw. juga bermakna perintah kepada seluruh perempuan Muslim. Selanjutnya, al-Qurtubî menegaskan bahwa perempuan hanya boleh keluar rumah bila dalam keadaan darurat. Tak jelas apa yang dimaksud dengan darurat dalam keterangan tersebut.

Menurut Ibn Kathîr, ayat di atas mengandung arti bahwa perempuan tidak dibenarkan keluar rumah kecuali ada kebutuhan yang dibenarkan oleh agama. Itupun dengan syarat dapat memelihara kesucian dan kehormatannya. Sedangkan Muhammad Qutb beranggapan bahwa ayat ini bukan berarti larangan terhadap perempuan untuk bekerja. Hanya saja, lanjut dia, Islam tidak mendorong hal tersebut. Islam membenarkan mereka bekerja karena darurat dan bukan menjadikannya dasar. Makna darurat di sini ialah pekerjaan-pekerjaan yang sangat perlu, yang dibutuhkan masyarakat atau atas dasar kebutuhan pribadi, karena tidak ada yang membiayai hidupnya dan/atau yang menanggung biaya hidupnya tidak mampu mencukupi kebutuhannya.

Dari penjelasan di atas, menurut Nasaruddin Umar, ${ }^{19}$ dapat diketahui bahwa para ahli tafsir memiliki keragaman pendapat dalam menafsirkan ayat 33 surah alAhzâb [33], ada yang melarang secara ekstrem, ada juga yang membolehkan perempuan bekerja di luar rumah dengan pelbagai persyaratan. Kalau dianalisis, sebenarnya ayat tersebut secara khusus ditujukan kepada istri-istri Nabi yang dalam banyak hal memiliki kekhususan. Persoalannya, mengapa perintah ini sepeninggal Nabi menjadi hukum normatif yang berlaku universal?

Boleh jadi, penafsiran dari al-Qurtubî dan Ibn Kathîr bias gender dan tampak bertentangan dengan kondisi perempuan di zaman Nabi. Sebab istri-istri nabi sendiri aktif dalam bidang ekonomi dalam beragam profesi, seperti: Siti Khadijah, konglomerat yang berhasil dalam bidang usah ekspor-impor, Safiyah bint Huyay, perias pengantin, dan Zainab bint Jahhsh, bekerja dalam bidang home industry pada proses menyamak kulit binatang.

Selain itu, menurut dia, perempuan-perempuan lain seperti Qilat Ummi banu Ammar yang pernah datang

\footnotetext{
${ }^{18}$ Al-Qurtubî, al-Jâmi' li Abhkâm al-Qur'ân, jilid I, h. 15.

${ }^{19}$ Nasarudin Umar, Fikih Wanita untuk Semua, h. 147.
}

kepada Nabi untuk meminta petunjuk mengenai jualbeli. Raitah, istri 'Abd Allâh ibn Mas'ûd, Sahabat Nabi yang aktif berbisnis karena suaminya tidak mampu mencukupi kebutuhan keluarga. Juga al-Shifâ, seorang perempuan yang ditugasi Umar mengurusi pasar di kota Madinah.

Menurut dia, banyak juga Hadis Nabi yang membolehkan perempuan bekerja di luar rumah, di antaranya:

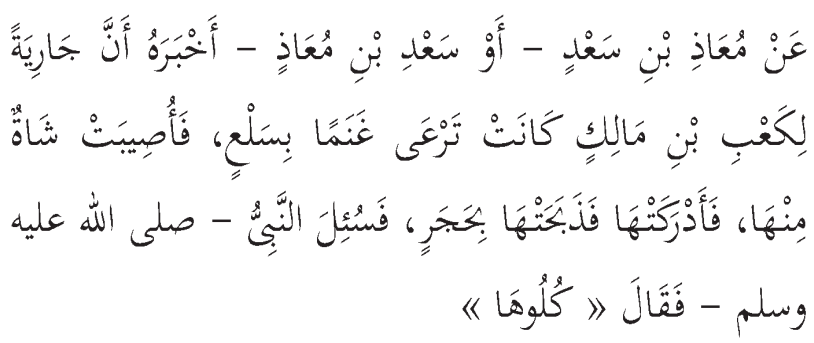

Dari Mu'âdh ibn Sa'ad diceritakan bahwa budak perempuan Ka'ab ibn Mâlik sedang menggembala kambingnya di Bukit Sala', lalu ada seekor kambing yang sekarat. Dia sempat mengetahuinya dan menyembelihnya dengan batu. Perbuatannya itu ditanyakan kepada Rasulullah Saw. Beliau menjawab, "Makan saja!" (H.r. al-Bukhârî) ${ }^{20}$

Dari Hadis di atas jelaslah bahwa Nabi membiarkan perempuan aktif dalam profesi peternakan. Bahkan, Nabi pernah memberikan petunjuk dalam praktik jual beli. Beliau bersabda bahwa apabila kamu ingin membeli atau menjual sesuatu, maka tetapkanlah harga yang kauinginkan untuk membeli atau menjualnya, baik kemudian kamu diberi atau tidak. Yang dimaksud Hadis tersebut adalah perempuan hendaknya jangan betele-tele dalam proses tawar-menawar. ${ }^{21}$

Secara historis, apa yang dilakukan Nabi merupakan reformasi yang luar biasa untuk menempatkan posisi perempuan setara dengan laki-laki, meskipun dalam awal sejarah Islam, kaum perempuan memperoleh kemerdekaan dan suasana batin yang cerah. Rasa percaya diri mereka semakin kuat sehingga di antara mereka mencatat prestasi gemilang, bukan saja di dalam sektor domestik, tetapi juga di ruang publik.

Namun demikian, menurut Nasaruddin Umar, kenyataan ini tidak berlangsung lama karena disebabkan banyak faktor, antara lain semakin berkembangnya dunia Islam sampai kepada pusat-pusat kerajaan yang bercorak misoginis, seperti: Damaskus, Baghdad, dan Persia. Di samping itu, unifikasi dan kodifikasi kitabkitab Hadis, Tafsir, dan Fikih yang banyak dipengaruhi oleh budaya lokal, langsung atau tidak lansung mem-

${ }^{20}$ Al-Bukhârî, Sahîh al-Bukhârî, (maktabah shâmilah), Bab Dhabihah al-Mar'ah, juz XVIII, h. 317, Hadis Nomor 5505.

${ }^{21}$ Fatimah Mernisi, Women and Islam, (London: Bisal Blackwell, 1991), h. 45. 
punyai andil dalam memberikan pembatasan hak dan gerak kaum perempuan sehingga semangat yang dihembuskan di masa awal Islam kurang mendapat perhatian atau mungkin sengaja tidak dikembangkan untuk mempertahankan ideologi tertentu. ${ }^{22}$

Selain itu, lanjut Nasaruddin, di dalam Alquran dan Hadis, tidak ditemukan larangan yang tegas bagi perempuan untuk memilih profesi, baik profesi itu dikerjakan secara sendiri atau secara kolektif, baik di lembaga-lembaga swasta maupun pemerintahan. Selama pekerjaan itu halal dan dilakukan dalam suasana terhormat serta mencegah hal-hal yang dapat menimbulkan kemudaratan.

Peluang berusaha bagi perempuan yang dilatarbelakangi seting sejarah sosial tersebut semakin tampak jelas dalam beberapa Hadis Nabi tentang usaha dalam bidang ekonomi. Hadis Nabi Muhammad Saw. yang dapat dijadikan rujukan terhadap peluang untuk mendirikan perusahaan adalah sebagai berikut:

$$
\text { إن الله يحب العبد المؤمن المخترف } 23
$$

Sesungguhnya Allah menyukai seorang hamba Mukmin yang mampu membuat perusahaan. (H.r.Tabrânî, alHakîm, Ibn Uday, Bayhaqî)

Menurut Nasarudin $\mathrm{Umar}^{24}$, Hadis ini ditujukan bukan hanya bagi laki-laki melainkan perempuan. Dalam usaha lain juga dikenal Sahabat Nabi Ummu Mubâshir (bercocok tanam/menanam korma) lewat Hadis Nabi berikut ini:

$$
\begin{aligned}
& \text { عن جابر: أن النبي صلى الله عليه وسلم دخل على أم مبشر } \\
& \text { الأنصارية في نخل لها فقال لها النبي صلى الله عليه و سلم } \\
& \text { (من غرس هذا النخل؟ أمسلم أم كافر؟) فقالت بل مسلم } \\
& \text { فقال (لا يغرس مسلما غرسا ولا يزرع زرعا فيأكل منه انسان } \\
& \text { ولا دابة ولا شيء إلا كانت له صدقة (رواه مسلم) }
\end{aligned}
$$

Dari Jabir dikatakan bahwa Nabi Saw. bertemu dengan Ummu Mubâshir perempuan Ansâr di dalam kebun kurma miliknya. Lalu Nabi berkata kepadanya, "Siapa yang menanam pohon kurma ini, orang Islam atau orang kafir?" Lantas Ummu Mubâshir berkata, "Orang Islam”. Rasulullah bersabda, "Tidaklah sorang Muslim menanam tumbuhtumbuhan lalu hasilnya dimakan oleh manusia, hewan atau sesuatu yang lain kecuali hal itu menjadi sedekah bagi yang menanamnya." (H.r. Muslim)

\footnotetext{
${ }^{22}$ Nasarudin Umar, Fikih Wanita untuk Semua, h. 150.

${ }^{23}$ Al-Suyûtn̂i, al-Jâmi' al-Kabîr, juz I, h. 8885 (maktabah shâmilah).

${ }^{24}$ Nasarudin Umar, Fikih Wanita untuk Semua, h. 151.

${ }^{25}$ Muslim, Sahbîh Muslim, juz III, h. 1188 .
}

Demikian pula peluang dalam industri rumah tangga (home industry). Berikut ini antara lain Hadis Nabi mengenai hal ini:

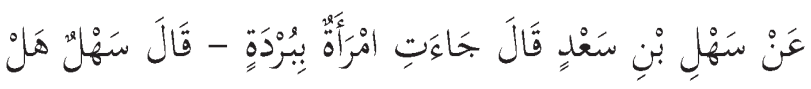

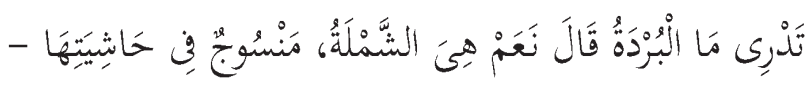

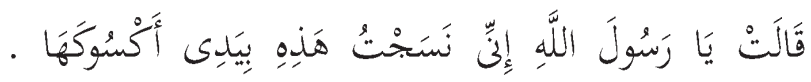

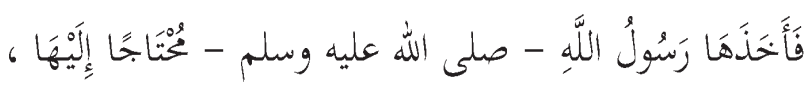

$$
\begin{aligned}
& { }^{26}{ }^{26}
\end{aligned}
$$

Dari Sahl ibn Sa'ad dikatakan tentang datangnya seorang perempuan dengan membawa burdah (kain lurik/selendang). Dia berkata, "Tahukah kalian apakah burdah itu? Ada yang menjawab, "Ya, ia adalah kain lurik yang disulam pada bagian pinggirnya." Perempuan itu berkata, "Ya Rasulullah, selimut itu aku sulam dengan tanganku sendiri yang akan aku pakaikan untukmu". Lantas Nabi Saw. mengambilnya sebagai suatu kebutuhannya. Kemudian Nabi keluar kepada kami dengan kain lurik tersebut yang beliau pakai sebagai selimut. (H.r. al-Bukhârî)

Selain itu, semua Ayat dan Hadis yang menyatakan keutamaan derajat manusia selalu tidak membedakan antara laki-laki dan perempuan. Karena itu, Alquran menggunakan istilah yang netral dalam pengungkapan tersebut, seperti dalam firman Allah berikut ini:

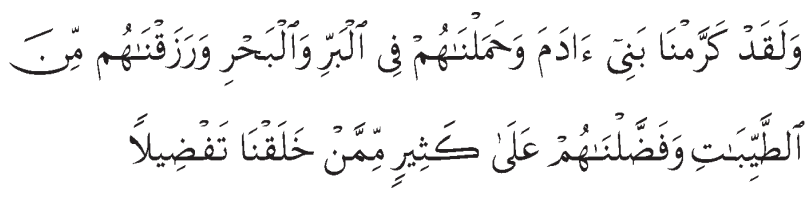

Dan sesungguhnya telah Kami muliakan anak-anak Adam. Kami angkut mereka di daratan dan di lautan. Kami beri mereka rezeki dari yang baik-baik dan Kami lebihkan mereka dengan kelebihan yang sempurna atas kebanyakan makhluk yang telah Kami ciptakan. (Q.s. al-Isrâ [17]: 70)

Menurut Nasarudin, kata بني ادم pada ayat di atas mencakup laki-laki dan perempuan. Peningkatan harkat dan martabat serta rezeki yang mereka peroleh terkait dengan prestasi yang mereka lakukan. Ayat-ayat yang menyatakan prestasi kemanusiaan sering dikaitkan dengan usaha-usaha setiap orang. Dengan demikian, ayat-ayat tersebut secara implisit menganjurkan perempuan untuk melakukan upaya-upaya aktif untuk mencapai prestasi tersebut. ${ }^{27}$

Di zaman Nabi, prestasi dan kesejahteraan ekonomi dapat diperoleh seorang perempuan cukup dengan menjadi ibu rumah tangga yang baik, dan semua

\footnotetext{
${ }^{26}$ Al-Bukhârî, S $\underline{\text { ahhîh }}$ al-Bukhârî, juz XIX, h. 298.

${ }^{27}$ Nasarudin Umar, Fikih Wanita untuk Semua, h.153.
} 
kebutuhannya akan diusahakan oleh suami. Namun, sekarang zaman sudah berubah dan kesejahteraan hidup tidak lagi bertumpu pada keluarga tetapi pada individu. Oleh karena itu, dengan sendirinya perempuan mendapatkan kesempatan, untuk melakukan kegiatan sebagaimana halnya laki-laki. Tentu saja, dengan tetap mempertahankan nilai-nilai agama, baik laki-laki maupun perempuan.

Selain itu, laki-laki dan perempuan mempunyai hak dan kewajiban yang sama dalam menjalankan peran khalifah dan hamba. Soal peran sosial dalam masyarakat, tidak ditemukan Ayat atau Hadis yang melarang kaum perempuan aktif di dalamnya. Sebaliknya, Alquran dan Hadis banyak mengisyaratkan kebolehan perempuan aktif menekuni pelbagai profesi. Dalam Alquran dinyatakan sebagai berikut:

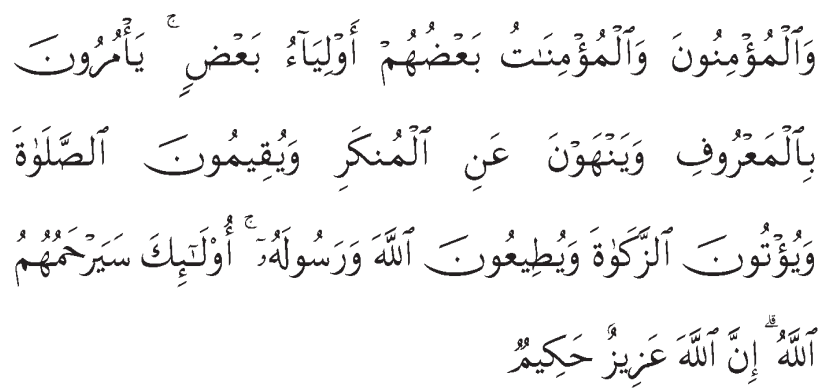

Dan orang-orang yang beriman, lelaki dan perempuan, sebagian mereka (adalah) menjadi penolong bagi sebagian yang lain. Mereka menyuruh (mengerjakan) yang makruf, mencegah dari yang munkar, mendirikan salat, menunaikan zakat, dan mereka taat pada Allah dan Rasul-Nya. Mereka itu akan diberi rahmat oleh Allah. Sesungguhnya Allah Mahaperkasa lagi Mahabijaksana. (Q.s. al-Tawbah [9]: 71)

Kata اولياء pada ayat di atas menurut M. Quraish Shihab mencakup kerjasama, bantuan, dan penguasaan. Sedangkan "menyuruh mengerjakan yang makruf" mencakup segala segi kebaikan, termasuk memberi masukan dan kritik terhadap penguasa. Dalam beberapa riwayat disebutkan betapa kaum perempuan pada masa permulaan Islam memegang peranan penting dalam kegiatan politik. Alquran dalam surah al-Mumtahanah [60] ayat 12 melegalisasi kegiatan politik kaum perempuan:

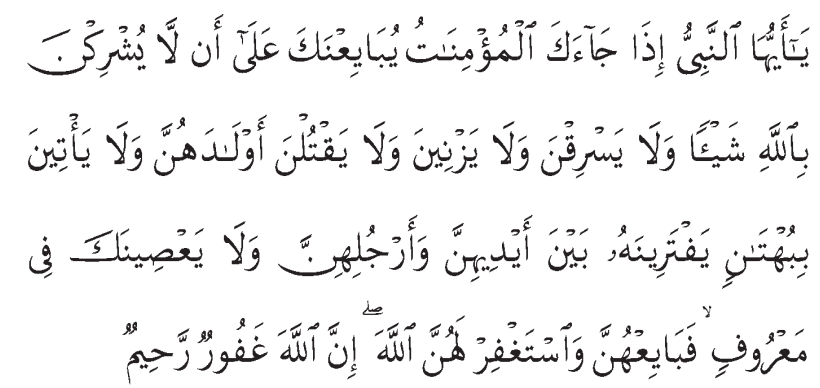

Hai Nabi, apabila datang kepadamu perempuan-perempuan yang beriman untuk mengadakan janji setia, bahwa mereka tiada akan menyekutukan Allah, tidak akan mencuri, tidak akan berzina, tidak akan membunuh anak-anaknya, tidak akan berbuat dusta yang mereka ada-adakan antara tangan dan kaki mereka dan tidak akan mendurhakaimu dalam urusan yang baik, maka terimalah janji setia mereka dan mohonkanlah ampunan kepada Allah untuk mereka. Sesungguhnya Allah Maha Pengampun lagi Maha Penyayang. (Q.s. al-Mumtahanah [60]: 12)

Istri-istri Nabi, terutama 'Â'ishah, telah menjalankan peran politik penting. Selain 'Â'ishah, juga banyak perempuan lain yang terlibat dalam urusan politik, mereka banyak terlibat di medan perang, dan tidak sedikit di antara mereka gugur di medan perang, seperti Ummu Salamah (istri Nabi), Safiyah, Laylah al-Ghaffariyah, dan Ummu Sinam al-Aslamiyah. Sedangkan kaum perempuan yang aktif di dunia politik dikenal, misalnya: Fâtimah bint Muhammad (Rasulullah), 'Â'ishah bint Abû Bakr, Atikah bint Yazîd ibn Muâwiyah, Ummu Salamah bint Ya'qûb, al-Khayzaran bint A'tak, dan lain sebagainya.

Demikian pula dalam bidang ekonomi, perempuan bebas memilih pekerjaan yang halal, baik di dalam maupun di luar rumah secara mandiri atau kolektif, di lembaga pemerintah atau swasta, selama pekerjaan itu dilakukan dalam suasana terhormat, sopan, dan tetap menghormati ajaran agamanya.

Di dalam Alquran dan Hadis, dengan demikian, tidak ditemukan larangan yang tegas bagi perempuan untuk memilih profesi, baik profesi itu dikerjakan secara sendiri atau secara kolektif, baik di lembagalembaga pemerintah maupun di lembaga-lembaga swasta, selama pekerjaan itu halal dan dilakukan dalam suasana terhormat, dan mencega hal-hal yang dapat menimbulkan kemudaratan. ${ }^{28}$

\section{Penutup}

Pemahaman klasik mengenai istri bekerja atau wanita karier yang harus digantungkan kepada izin suami perlu di baca ulang atau ditinjau kembali karena para ulama tidak menyuguhkan argumentasi yang jelas tentang hal itu. Dan juga tidak adanya dalil yang melarang, baik lakilaki maupun perempuan untuk bekerja, serta tidak ada dalil yang tegas tentang keharusan izin suami bagi istri yang akan bekerja atau berkarier. Begitu juga tidak sedikit fakta sejarah yang mengungkapkan wanita-wanita yang bekerja atau wanita karier di masa Rasulullah, seperti 'Â'ishah, Ummu Mubâshir, dan lain-lain.[]

\footnotetext{
${ }^{28}$ Nasarudin Umar, Fikih Wanita untuk Semua, h. 157.
} 


\section{Pustaka Acuan}

Abû al-Barakat, al-Muharrar fi al-Fiqh 'alâ Madhhab

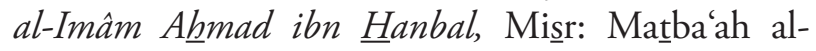
Sunniyyah, t.th.

Ahnmad ibn Hanbal, Musnad A $\underline{h m a d, ~ S a u d i ~ A r a b i a: ~}$ Maktabah Syamilah, t.th.

Azzam, Abdul Aziz Muhammad dan Hawwas, Abdul Wahhab Sayyed, Fiqh Munakahat, terj. Abdul Majid Khon, cet. I, Jakarta: AMZAH, 2009.

Bayhaqî, al-, al-Sunan al-Kubrâ, Saudi Arabia: Maktabah Shâmilah, t.th.

Bukhârî, al-, S $\underline{\text { ahîh }} \underline{h}$ al-Bukhârî, Bâb Dhâbihah alMar'ah, juz XVIII, Bayrut: Dâr Ihyâ al-Kutub al'Arabiyyah, t.th.

Dardiri, al-, al-Sharh al-Kabir, Missr: Dâr Ihyầ al-Kutub al-'Arabiyyah, t.th.

Hawwa, al-, Faid, al-Asas fi al-Tafsîr, Juz VIII, Misir: Dâr al-Salâm, 1999.

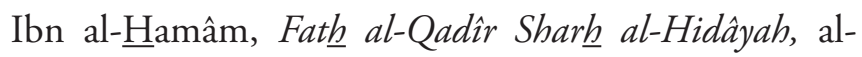
Qâhirah: Matba'ah Mustafâ Muhammaad, t.th.

Ibn Kathîr, Tafsîr ibn Kathîr, Juz III, Bayrût: Dâr al-Fikr 1986.

Ibn Qudâmah, al-Mughnî, cet. III, al-Qâhirah: Dâr alManâr, t.th.

Ibn Rushd, Bidâyah al-Mujtahid, Misir: Matba'ah alIstiqâmah, t.th.

Mâlik ibn Anas, al-Mudawwanah al-Kubrâ Riwayat Sahnun, Matba'ah al-Sa âdah, $1323 \mathrm{H}$.

Maraghî, al-, Aḥmad Mustafâ, Tafsîr al-Maraghî, Juz VIII, Bayrût: Dâr al-Fikr, t.th.

Marcoes, Lies M. dan Meuleman, Johan Hendrik, Perempuan Islam Indonesia dalam Kajian Tekstual dan Konstekstual, Jakarta: INIS, 1993.

Mernisi, Fatimah, Women and Islam, London: Bisal Blackwell, 1991.

Muhammad, Husen, Figh Perempuan, Yogyakarta: LKIS, 2001.

Muslim, Sahbih Muslim, Juz III, Bayrût: Dâr Ihyâa alKutub al-'Arabiyyah, t.th.
Nawawi al-Bantani, Marah al-Labid Tafsir al-Munir, juz III, Bayrût: Dar al-Fikr, 1981.

---_----, Sharh 'Uqûd al-Lujayn, Indonesia: Dâr Ihyâ al-Kutub al-'Arabiyyah, t.th.

Nuriyah, Shinta, Forum Kajian Kitab Kuning (FK3), Ta liq wa Takhrij 'alâ Shark 'Uqudal-Lujayn fi Bayân Huqûq al-Zawjayn, Jakarta: FK3, t.th.

Qurtubî, al-, al-Jâmi li A Abkâm al-Qurân, Misrr: alBulaq, t.th.

Ramlî, al-, Nihâyah al-Muḅtâj, Misrr: Matba'ah alBahiyah, t.th.

Sarkhasî, al-, al-Mabsuth, cet. I, Bayrût: Matba'ah Sa âdah, t.th.

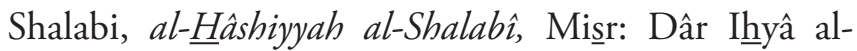
Kutub al-Arabiyyah, t.th.

Sharbinî, Mughnî al-Muntaj Sharh al-Minhâj, Misir:

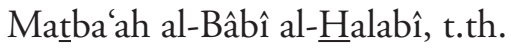

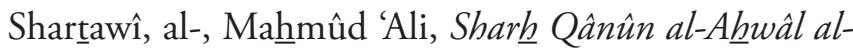
Shakhshiyyah, Amman: Dâr al-Fikr, 1997.

Shawkânî, al-, Nayl al-Awtârr, al-Qâhirah: Mustafầ Albâb al- $\underline{\text { Halabî, t.th. }}$

Shirâzî, al-, Abû Ishâq, al-Muhadhdhab, Jilid II, Mišr: Isa al-Bâbî wa Shurakâuh, t.th.

Suyutîi, al-, al-Jâmi’ al-Kabîr, juz I, Bayrût: Dâr Ihyyâ alKutub al-'Arabiyyah, t.th.

Suyûtí, al-, Jalâl al-Dîn dan Mahallî̀, al-, Jalâl al-Dîn, Tafsîr al-Jalâlayn, Juz II, Indonesia: Dâr Ihyâ alKutub al-Arabiyyah, t.th.

Syarifudin, Amir, Hukum Perkawinan Islam di Indonesia, Cet. III, Jakarta: Kencana Prenada Media Group, 2009.

Tabarî, al-, Tafsîr al-abarî̀, Jilid XXII, Bayrût: Dâr Ihyâ al-Kutub al-'Arabiyyah, t.th.

Turmudhî, al-, Sunan al-Turmudhî, juz IV, Bayrût: Dâr Ihyầ al-Turâth al-Islâmî, t.th.

Umar, Nasarudin, Fikih Wanita untuk Semua, Jakarta: Serambi Ilmu, 2010.

Zuhaylî, al-, Wahbah, al-Fiqh al-Islâmî wa Adillatuh, Bayrût: Dâr al-Fikr, 1996. 